\title{
Teacher's Perception on Transformational Leadership Based on Primary Schools in Peninsular Malaysia
}

\author{
Indra Devi Maniam*, Aminuddin Hassan, Arnida Abdullah, Noraziela Abdul Majid \\ Faculty of Educational Studies, University Putra Malaysia
}

*Corresponding Author: Indra Devi Maniam, Faculty of Educational Studies, University Putra Malaysia

\begin{abstract}
The purpose of this study is to determine the level of transformational leadership practices based on three types of schools in Peninsular Malaysia. A total of 432 teachers from 72 primary schools from four states of Peninsular Malaysia were selected based on stratified random sampling. Descriptive statistic and analysis of One-way ANOVA was used to analyse the primary data collected through survey method. Leith wood and Jantzi, (1995) questionnaire was utilized to measure transformational leadership. The result showed that the level of transformational leadership was high based on teachers' perception from the three types of schools. Moreover, the findings also revealed that there was significant difference between the level of transformational leadership dimensions based on teachers' perception at National, National type Chinese and National type Tamil schools. Furthermore, the practices of transformational leadership were significantly higher at National type Tamil schools compared to National and National type Chinese schools.
\end{abstract}

Key words: Transformational Leadership, Primary Schools, Type of Schools, Peninsular Malaysia

\section{INTRODUCTION}

Educational organizations have witnesses a rapid change since the last decade with effort to increase effectiveness. Like many other countries, Malaysian education system also faced tremendous changes and transformation. The Malaysia Education Blueprint 2013-2025 was implemented in accordance to bring positive and sustainable transformation to the Malaysian education system. The fifth shift of the reformation highlights the need of ensuring high-performing schools leaders in schools (Ministry of Education, 2013). As such, in line with current reformation and transformation in the Malaysian education context, the transformational leadership received the most attention as an ideal leadership in bring about the changes into schools (Khalip Musa, 2013). Moreover, this leadership style has gained support in the literature and has been recommended as an appropriate model of school leadership especially to schools that faces $21^{\text {st }}$ century challenges (Nir \& Hameiri, 2013; Talebloo et al., 2015; Leithwood \& Jantzi, 2006). According to Jamilah Man et al. (2016), in order to be in line with current National Educational Blueprint (2013-2025), a leader should practice all the dimensions of transformational leadership at its best.

\section{LITERATURE REVIEW}

Transformational Leadership was first introduced by Burns (1978). The rudimentary foundation of transformational leadership theory resolves around the importance of transforming other into leaders. However, this theory then was improvised over the periods revising all the scantiness by the earlier researchers. Formerly, Burns theory was based on Maslow's hierarchy of needs. According to him, transformational leadership could raise followers from a lower level to a higher level of morality and motivation. However, Bass (1985) refined and expended Burns' leadership theory by stating that leader encourages the followers to go beyond self-interest for the good of the team or organization. This Bass theory more focused on the exchanges between leader and followers inside the organizations. Then, Bass and Avolio (1998) introduced the theory of Full Range of Leadership whereby through the theory, identification and training of potential leader were investigated more systematically.Leith wood and his colleagues have been instrumental in bridging the work of Burns and Bass into fields of educational administration. Thus, in order to describe the transformational leadership, Leith wood (1994) conceptualized eight dimensions which are categorized into three groups: (1) setting direction (building school vision, establishing school goals, demonstrating high 
performance expectations), (2) developing people (providing intellectual stimulation, offering individualized support, models the best practices and important organizational values) and (3) redesigning the organization (creating a productive school culture and developing structures to foster participation in school decisions) (Leith wood, 2012). This model was able to establish a framework of transformational leadership that can be allied with specific transformational leadership practices and problem-solving processes in school. According to this model, in a successful transformational leadership at schools, all the eight aspect have to be considered.

- Developing a shared vision

Transformational leader demonstrates behaviours that enact to identify new opportunities to articulate and in same time inspire the staff with vision of the future (Sun \& Leith wood, 2012).

\section{- Building goal consensus}

Transformational leader behaviours that make consensus among the staffs about the significance of common goal and in the same time encourage cooperation among school staffs and assisting them to work together towards achieving the common goal (Leith wood ,2012).

- Holding high performance expectations

Transformational leader behaviours that anticipate a high standard of professionalism from staff and expect them to be effective innovators (Leith wood, 2012; Baharak Talebloo, 2015).

\section{- Providing individualized support}

Transformational leader behaviours that include respect for individual staff and concern about their individual feelings and needs (Leithwood, 2012; Salleh \& Saidova, 2013).

\section{- Providing intellectual stimulation}

Transformational leader's practices which challenge the staff to re-examine their assumptions about their work and provide information to staff members to assists them evaluate their practices, refine them and performing them effectively (Leith wood, Harris \& Hopkins, 2008; Leith wood, 2012; Saybani et al., 2013).

\section{- Model behaviour}

Transformational leader serve as role model of appropriate ethical behaviour, respecting and trusting in the staff, exemplifying success and representing an inclination to change individual's practices based on new understanding and condition in the schools (Leith wood, 2012)

\section{- $\quad$ Strengthening school culture}

Transformational leadership behaviours that successfully build the shared norms, beliefs, values and assumptions of the school members (Leith wood, Jantzi \& Steinbach, 1999)

\section{- Building Collaborative structures}

According to Leith wood, Jantzi \& Steinbach (1999), building collaborative structure refers to transformational leader at the school able to create formal and informal opportunities for school members to give their professional input for decision-making.

\subsection{Problem Statement}

Malaysian government have carefully structured many programmed for realizing the Malaysian Education Blueprint 2013-2015 such as new KSSR (Primary School Standard Curriculum), PBS (School-based Assessment) and HOTS (Higher Order Thinking Skills) (Kamaruddin et al.,2017) at National, National type Chinese and National type Tamil schools. All these transformations, has put a great pressure on the leader at primary schools as primary school become pioneer platform for implementing the new curriculum (Hassan et al., 2010). Moreover, leader plays vital roles as agent of transformation at school level (Hassan et al., 2015). Most of the studies carried out in Malaysia focusing on the relation between transformational leadership and student achievement (Davrajoo et al., 2010; Talebloo et al., 2015). However, reviewing past study indicated that few researches has been done on determined level of transformational leadership based on demographic particularly based on three types of schools in local setting. 


\section{OBJECTIVE OF THE STUDY}

The main objectives of the study are:

- To determine the level of headmasters' transformational leadership based on teachers' perception at three types of primary schools in Peninsular Malaysia.

- To determine the significant difference between the levels of headmasters' transformational leadership based on three types of primary schools.

\section{Methodology}

This study was based on research survey using quantitative method. The instrument measuring multidimensional construct of transformational leadership was adapted from Leith wood \& Jantzi (1995) with modification to suit the purpose of this study. It consists of 49 items measuring the eight dimensions of headmasters' transformational leadership (1) Developing a Shared Vision, (2) Building Goal Consensus, (3) Holding High Performance Expectations for Success, (4) Model Behaviour, (5) Providing Individualized Support, (6) Providing Intellectual Stimulation, (7) Strengthening School Culture and (8) Building Collab orative Structures. A 5-point Likert scale ranging from $1=$ Strongly Disagree to $5=$ Strongly Agree was used to engage the respondents' respond. There were 432 primary school teachers participated in this study. The descriptive statistics (mean, standard deviation and level) and inferential statistics (One-way ANOVA) was used to determine the level and significant differences of headmasters' transformational leadership at three types of schools in Peninsular Malaysia.

\section{FINDINGS}

\subsection{To determine the level of headmasters' transformational leadership based on teachers' perception at three types of primary schools in Peninsular Malaysia.}

Table1. Mean and Standard Deviation of Overall Transformational Leadership for the Three Types of Schools

\begin{tabular}{|c|c|c|c|c|c|c|c|}
\hline \multirow{3}{*}{\multicolumn{2}{|c|}{ Dimension / Items }} & \multicolumn{6}{|c|}{ Types of School } \\
\hline & & \multicolumn{2}{|l|}{ SK } & \multicolumn{2}{|c|}{ SKJ (C) } & \multicolumn{2}{|c|}{ SKJ (T) } \\
\hline & & Mean & SD & Mean & SD & Mean & SD \\
\hline 1 & Developing a Shared Vision & 4.39 & .537 & 4.38 & .489 & 4.53 & .569 \\
\hline 2 & Building Goal Consensus & 4.38 & .573 & 4.34 & .514 & 4.52 & .523 \\
\hline 3 & $\begin{array}{l}\text { Holding High Performance Expectations } \\
\text { for Success }\end{array}$ & 4.54 & .475 & 4.47 & .459 & 4.63 & .444 \\
\hline 4 & Model Behaviour & 4.37 & .517 & 4.40 & .538 & 4.60 & .504 \\
\hline 5 & Providing Individualized Support & 4.27 & .591 & 4.28 & .542 & 4.57 & .569 \\
\hline 6 & Providing Intellectual Stimulation & 4.25 & .546 & 4.22 & .513 & 4.51 & .591 \\
\hline 7 & Strengthening School Culture & 4.37 & .559 & 4.42 & .484 & 4.61 & .542 \\
\hline 8 & Building Collaborative Structures & 4.21 & .562 & 4.20 & .533 & 4.49 & .617 \\
\hline \multicolumn{2}{|c|}{ Overall } & 4.34 & .545 & 4.34 & .509 & 4.56 & .545 \\
\hline
\end{tabular}

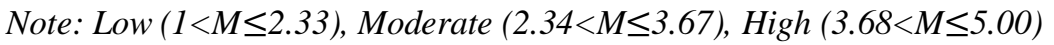

Table2. Perception Level of Overall Transformational Leadership for the Three Types of Schools

\begin{tabular}{|l|l|l|l|l|l|l|l|}
\hline \multirow{2}{*}{ Dimension / Items } & \multicolumn{2}{|l|}{ Types of School } & \multicolumn{5}{l|}{ SKJ (C) } \\
\cline { 3 - 8 } & SK & LKJ (T) \\
\cline { 2 - 8 } & Level & Rank & Level & Rank & Level & Rank \\
\hline 1 & Developing a Shared Vision & High & 2 & High & 4 & High & 5 \\
\hline 2 & Building Goal Consensus & High & 3 & High & 5 & High & 6 \\
\hline 3 & Holding High Performance & High & 1 & High & 1 & High & 1 \\
& Expectations for Success & & & & & & \\
\hline 4 & Model Behavior & High & 4 & High & 3 & High & 3 \\
5 & Providing Individualized Support & High & 5 & High & 6 & High & 4 \\
6 & Providing Intellectual Stimulation & High & 6 & High & 7 & High & 7 \\
7 & Strengthening School Culture & High & 4 & High & 2 & High & 2 \\
8 & Building Collaborative Structures & High & 7 & High & 8 & High & 8 \\
\hline Overall & High & & High & & High & \\
\hline
\end{tabular}

Table 1 and Table 2 show teachers' perception on the level of overall transformational leadership practices in their school. Transformational leadership comprised of eight dimensions (developing a 
shared vision, building goal consensus, holding high expectation for success, model behaviour, providing individualized support, providing intellectual stimulation, strengthening school culture and building collaborative structures). Overall, the findings indicated that the teachers' from National (SK), National type Chinese (SJK(C)) and National type Tamil (SJK (T)) rated all dimensions at high level. The dimension that shows the highest level at SK schools is item 3, holding high expectation for success $(\mathrm{M}=4.54, \mathrm{SD}=.475)$. This is followed by item 1 , developing a shared vision $(\mathrm{M}=4.39, \mathrm{SD}=$ $.537)$, item 2 building goal consensus $(\mathrm{M}=4.38, \mathrm{SD}=.573)$, item 4 model behaviour $(\mathrm{M}=4.37, \mathrm{SD}=$ $.517)$, item 5 providing individualized support $(\mathrm{M}=4.27, \mathrm{SD}=.591)$ and item 6 providing intellectual stimulation $(\mathrm{M}=4.25, \mathrm{SD}=.546)$. The last item with high score is item 8 , building collaborative structure $(\mathrm{M}=4.21, \mathrm{SD}=.562)$. Overall, the score for transformational leadership is at high level $(\mathrm{M}=$ $4.34, \mathrm{SD}=.545$ ). This shows that teachers perceived the overall transformational leadership practices by the SK schools' headmasters are at high level.

According to the result, the dimension that indicated the highest level at $\operatorname{SJK}(C)$ schools is item 3, holding high expectation for success $(\mathrm{M}=4.47, \mathrm{SD}=.459)$. This is followed by item7, strengthening school culture $(M=4.42, S D=.484)$. The third highest item is item 4 , model behaviour $(M=4.40$, $\mathrm{SD}=.538)$. This is followed by item1, developing a shared vision dimension $(\mathrm{M}=4.38, \mathrm{SD}=.489)$. Building goal consensus is the fifth item with high level $(\mathrm{M}=4.34, \mathrm{SD}=.514)$. The next item with high level is item 5, providing individualized support $(\mathrm{M}=4.28, \mathrm{SD}=.542)$. This is followed by item 6 , providing intellectual stimulation $(\mathrm{M}=4.22, \mathrm{SD}=.513)$. The lowest transformational dimension with high level is building collaborative structure $(\mathrm{M}=4.20, \mathrm{SD}=.533)$. Overall, the score for transformational leadership practices at $\mathrm{SKJ}(\mathrm{C})$ school is at high level $(\mathrm{M}=4.34, \mathrm{SD}=.509)$, which shows that the teachers perceived the level of transformational leadership at $\mathrm{SJK}(\mathrm{C})$ schools at high level.

Based on the result at $\mathrm{SJK}(\mathrm{T})$ school, the dimension with the highest level is holding high performance expectation $(\mathrm{M}=4.63, \mathrm{SD}=.444)$. This is followed by second high level dimension is strengthening school culture $(\mathrm{M}=4.61, \mathrm{SD}=.542)$. The next dimension with the high level is model behaviour $(M=4.60, S D=.504)$. This is followed by providing individualized support dimension $(M=$ $4.57, \mathrm{SD}=.569)$. Developing a shared vision is the fifth dimension with high level $(\mathrm{M}=4.53, \mathrm{SD}=$ $.569)$. The next dimension with high level is building goal consensus $(\mathrm{M}=4.52, \mathrm{SD}=.523)$. This is followed by providing intellectual stimulation $(\mathrm{M}=4.51, \mathrm{SD}=.591)$. The lowest transformational dimension with high level is building collaborative structure $(\mathrm{M}=4.49, \mathrm{SD}=.617)$. Overall, the score for transformational leadership practices at $\mathrm{SKJ}(\mathrm{T})$ school is at high level $(\mathrm{M}=4.56, \mathrm{SD}=.545)$. This shows that the teachers perceived the level of transformational leadership at $\mathrm{SJK}(\mathrm{T})$ schools at high level.

\subsection{To Determine the Significant Difference Between the Levels of Headmasters' Transformational Leadership Based on Three Types of Primary Schools}

Table 3 shows the One-Way ANOVA of respondents' perception on transformational leadership based on three types of schools (National=SK, National type Chinese=SJK(C) and National type Tamil (SJK (T)). One-Way ANOVA test was employed to investigate if there was a significant difference in respondents' perception of transformational leadership based on types of schools. The result on Table 3 revealed that there was a statistically significant difference in the mean scores of developing the shared vision ( $\mathrm{F}=3.649, \mathrm{p}>.027)$, building goal consensus $(\mathrm{F}=4.085, \mathrm{p}>.017)$, holding high performance expectation $(\mathrm{F}=4.521, \mathrm{p}>.011)$, model behaviour $(\mathrm{F}=7.780, \mathrm{p}>.000)$, providing individualized support $(\mathrm{F}=12.074, \mathrm{p}>.000)$, providing intellectual stimulation $(\mathrm{F}=11.260, \mathrm{p}>.000)$, strengthening school culture $(\mathrm{F}=7.457, \mathrm{p}>.001)$, building collaborative structure $(\mathrm{F}=11.479, \mathrm{p}>.000)$ and overall transformational leadership $(\mathrm{F}=9.414, \mathrm{p}>.000)$ between $\mathrm{SK}, \mathrm{SJK}(\mathrm{C})$ and $\mathrm{SJK}(\mathrm{T})$ schools.

Table3. One-way ANOVA test of Transformational Leadership Level based on Type of School

\begin{tabular}{|l|l|l|l|l|l|l|l|}
\hline \multicolumn{2}{|c}{} & N & M & SD & Mean square & F & Sig \\
\hline Developing Shared Vision & SK & 150 & 4.3867 & .53679 & 1.026 & 3.649 & .027 \\
\cline { 2 - 9 } & SJK(C) & 154 & 4.3805 & .48871 & .281 & & \\
\cline { 2 - 9 } & SJK(T) & 128 & 4.5344 & .56908 & & & \\
\cline { 2 - 9 } & Total & 432 & 4.4282 & .53346 & & & \\
\hline
\end{tabular}


Teacher's Perception on Transformational Leadership Based on Primary Schools in Peninsular Malaysia

\begin{tabular}{|c|c|c|c|c|c|c|c|}
\hline \multirow[t]{4}{*}{ Building Goal Consensus } & SK & 150 & 4.3767 & .57474 & 1.184 & 4.085 & .017 \\
\hline & SJK(C) & 154 & 4.3442 & .51376 & .290 & & \\
\hline & $\mathrm{SJK}(\mathrm{T})$ & 128 & 4.5195 & .52272 & & & \\
\hline & Total & 432 & 4.4074 & .54213 & & & \\
\hline \multirow[t]{4}{*}{ Holding High Performance Expectation } & SK & 150 & 4.5367 & .47451 & .956 & 4.521 & .011 \\
\hline & $\operatorname{SJK}(\mathrm{C})$ & 154 & 4.4675 & .45885 & .212 & & \\
\hline & $\mathrm{SJK}(\mathrm{T})$ & 128 & 4.6328 & .44361 & & & \\
\hline & Total & 432 & 4.5405 & .46368 & & & \\
\hline \multirow[t]{4}{*}{ Model Behaviour } & SK & 150 & 4.3676 & .51716 & 2.109 & $7 . .780$ & .000 \\
\hline & $\mathrm{SJK}(\mathrm{C})$ & 154 & 4.4026 & .53762 & .271 & & \\
\hline & $\operatorname{SJK}(\mathrm{T})$ & 128 & 4.5993 & .50358 & & & \\
\hline & Total & 432 & 4.4487 & .52875 & & & \\
\hline \multirow[t]{4}{*}{ Providing Individualized Support } & SK & 150 & 4.2733 & .59100 & 3.885 & 12.074 & .000 \\
\hline & $\operatorname{SJK}(\mathrm{C})$ & 154 & 4.2760 & .54170 & .322 & & \\
\hline & $\operatorname{SJK}(\mathrm{T})$ & 128 & 4.5684 & .56880 & & & \\
\hline & Total & 432 & 4.3617 & .58162 & & & \\
\hline \multirow[t]{4}{*}{ Providing Intellectual Stimulation } & SK & 150 & 4.2505 & .54642 & 3.389 & 11.260 & .000 \\
\hline & $\mathrm{SJK}(\mathrm{C})$ & 154 & 4.2199 & .51291 & .301 & & \\
\hline & $\operatorname{SJK}(\mathrm{T})$ & 128 & 4.5078 & .59101 & & & \\
\hline & Total & 432 & 4.3158 & .56147 & & & \\
\hline \multirow[t]{4}{*}{ Strengthening School Culture } & SK & 150 & 4.3724 & .55782 & 2.077 & 7.457 & .001 \\
\hline & $\operatorname{SJK}(\mathrm{C})$ & 154 & 4.4249 & .48423 & .279 & & \\
\hline & $\mathrm{SJK}(\mathrm{T})$ & 128 & 4.6083 & .54176 & & & \\
\hline & Total & 432 & 4.4610 & .53566 & & & \\
\hline \multirow[t]{4}{*}{ Building CollaborativeStructure } & SK & 150 & 4.2067 & .56219 & 3.714 & 11.479 & .000 \\
\hline & $\mathrm{SJK}(\mathrm{C})$ & 154 & 4.1997 & .53274 & .324 & & \\
\hline & $\operatorname{SJK}(\mathrm{T})$ & 128 & 4.4902 & .61670 & & & \\
\hline & Total & 432 & 4.2882 & .58251 & & & \\
\hline \multirow[t]{4}{*}{ Transformational Leadership } & SK & 150 & 4.3463 & .48033 & 2.079 & 9.414 & .000 \\
\hline & $\operatorname{SJK}(\mathrm{C})$ & 154 & 4.3394 & .43686 & .221 & & \\
\hline & SJK(T) & 128 & 4.5576 & .49551 & & & \\
\hline & Total & 432 & 4.4064 & .47907 & & & \\
\hline
\end{tabular}

Table4. Post-Hoc Tukey (HSD) of Transformational Leadership by Types of School

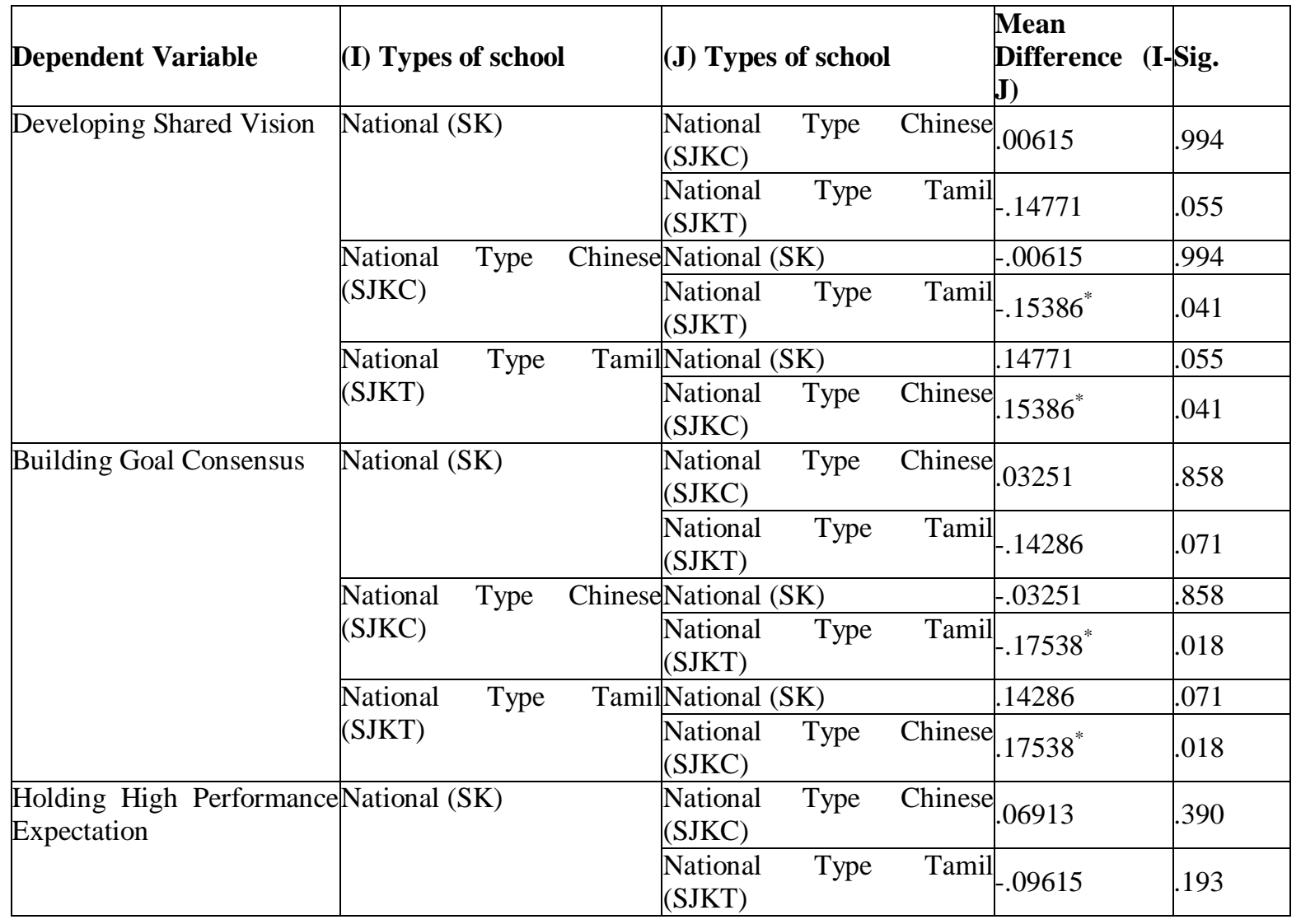




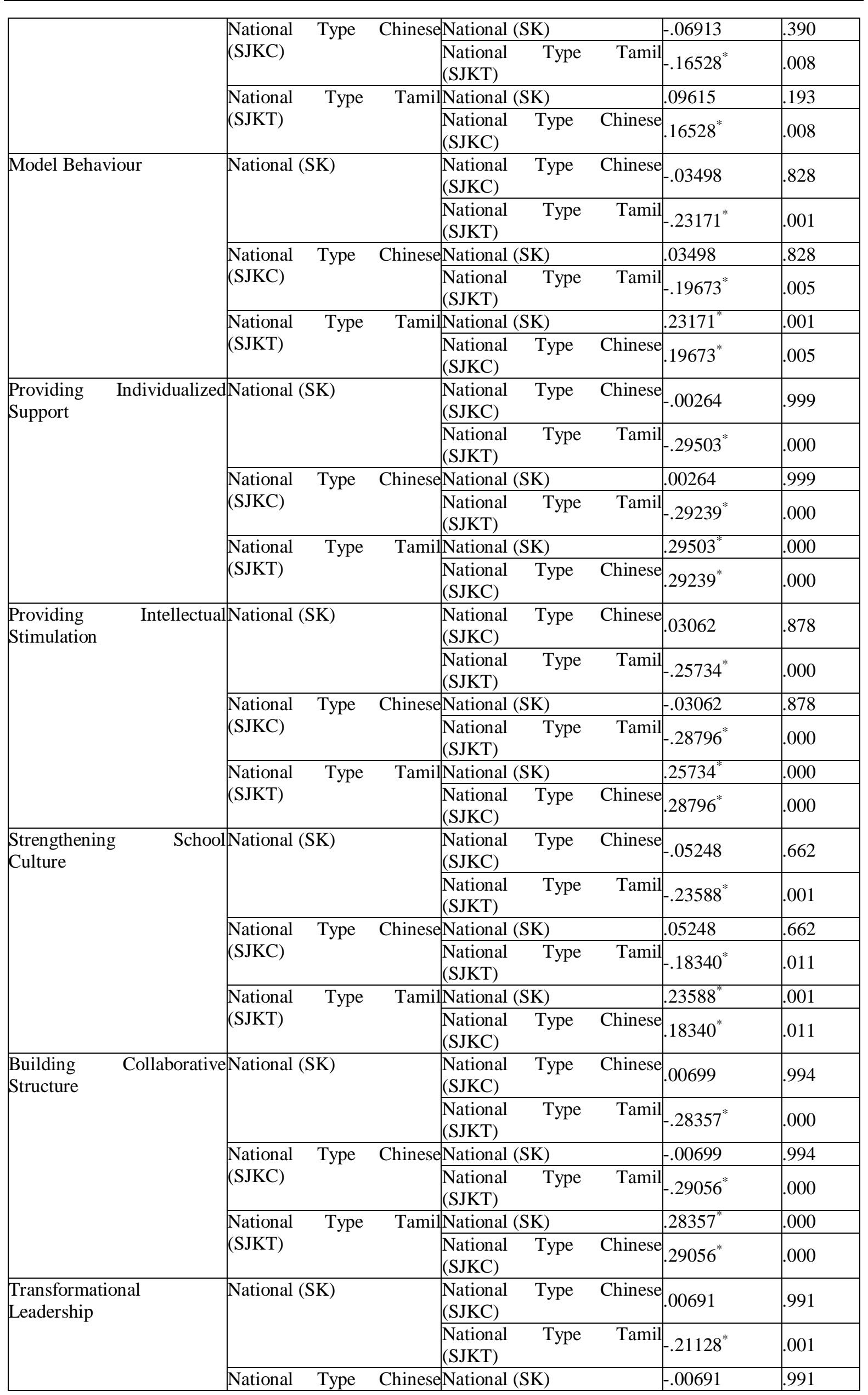




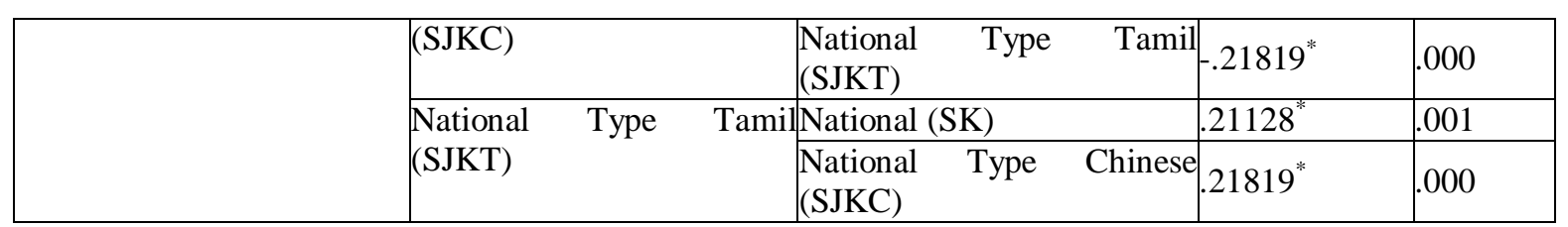

The Tukey Post-Hoc test was applied to determine which type of school differed from the other types in developing a shared vision, building goal consensus, holding high performance expectations, model behaviour, providing individualized support, providing intellectual stimulation, strengthening school culture, building collaborative structures and overall transformational leadership dimension. Based on Table 4, the teachers perceived the level of developing the shared vision is significantly higher in the SJK $(T)$ schools $(M=4.534)$ compared to SJK $(C)$ schools $(M=4.381)$. The teachers' perception on the level of building goal consensus is significantly higher in the SJK $(\mathrm{T})$ schools $(\mathrm{M}=4.520)$ compared to SJK(C) schools $(M=4.344)$. The result also indicated that the teachers' perception on the level of holding high performance expectation is significantly higher in the SJK $(\mathrm{T})$ schools $(\mathrm{M}=4.633)$ compared to $\operatorname{SJK}(\mathrm{C})$ schools $(\mathrm{M}=4.468)$. The result on the level of model behaviour indicated that the SJK (T) schools $(M=4.402)$ is significantly higher compared to SK schools $(M=4.368)$ and $\mathrm{SJK}(\mathrm{C})$ schools $(\mathrm{M}=4.403)$. The teachers' perception on the level of providing individualized support indicated that SJK $(\mathrm{T})$ schools $(\mathrm{M}=4.568)$ is significantly higher compared to SK schools $(\mathrm{M}=4.273)$ and $\operatorname{SJK}(\mathrm{C})$ schools $(\mathrm{M}=4.276)$. As for the teachers' perception on the level of providing individualized stimulation indicated that SJK $(\mathrm{T})$ schools $(\mathrm{M}=4.508)$ is significantly higher compared to $\mathrm{SJK}(\mathrm{C})$ schools $(\mathrm{M}=4.220)$ and SK schools $(\mathrm{M}=4.251)$. The teachers' perceived the level of strengthening school culture is significantly higher for SJK $(\mathrm{T})$ schools $(\mathrm{M}=4.608)$ is significantly higher compared to SK schools $(M=4.372)$ and $\operatorname{SJK}(C)$ schools $(M=4.425)$. The teachers' perception on the level of building collaborative structures indicated that SJK (T) schools $(\mathrm{M}=4.490)$ is significantly higher compared to $\mathrm{SJK}(\mathrm{C})$ schools $(\mathrm{M}=4.200)$ and SK schools $(\mathrm{M}=4.207)$. As for the overall teachers' perception on the level of transformational leadership indicated that SJK (T) schools $(M=4.556)$ is significantly higher compared to $\operatorname{SJK}(C)$ schools $(M=4.334)$ and SK schools $(M=$ 4.346).

Overall, it can be concluded that, there was significant differences between transformations leadership's dimensions (developing a shared vision, building goal consensus, holding high performance expectations, model behaviour, providing individualized support, providing intellectual stimulation, strengthening school culture, building collaborative structures) and overall transformational leadership dimensions based on types of school as perceived by teachers. The teachers' perceived the level of all the transformational leadership dimensions is significantly high at SJK (T) schools compared to SJK(C) and SK schools.

\section{CONCLUSION}

The result of the descriptive statistics indicated that all the teachers' from SK, SJK (C) and SJK(T) in Peninsular Malaysia had a high level of transformational leadership perception in their school.Therefore, it can be concluded that, as perceived by the teachers from all the three types of schools, their headmaster practices a high level of transformational leadership in the schools. The result are in line with the findings by Talebloo et al., (2015) at primary schools in Selangor, Veeriah, J. et al., (2017) in Selangor cluster schools, Selamat, Noordin \& Adnan (2013), Khalip Musa (2013), Teh et al., (2015), Wahab et al., (2014) and Ling \& Pihie (2014) findings among the Malaysian schools, indicated a high level of overall transformational leadership practices among the headmasters.

The result of this study also revealed that the most practiced dimension of transformational leadership at the three types of schools (SK, SJK (C), and SJK (T)) was holding high performance expectations for success dimension. The result of this study was in line with Yu, Leith wood \& Jantzi (2002) findings among 1140 primary teachers in Hong Kong, Talebloo (2015) and Jeyasushma Veeriah (2017) findings in Malaysian primary schools who reported that the most practiced dimension of transformational leadership behaviours was holding high performance expectations for success. The result of this study also revealed that the least practiced dimension was building collaborative structure. The findings, however, inconsistent with Talebloo (2015) and Veeriah, J. (2017) findings as they reported the least practiced dimension of headmaster's transformational leadership behaviour was providing individualized support (Talebloo, 2015) and developing a shared vision (Veeriah, J., 2017). 
Result of analysis on the level of transformational leadership based on types of schools indicated that there was significant difference between the transformational leadership's dimensions and overall transformational leadership in three types of primary schools in Peninsular Malaysia. These results was consistent with Ismail et al. (2013), Majid et al. (2019)and Salleh \& Saidova (2013) findings among multi-ethnic head teachers of various types of primary schools in Sabah state in Malaysia, who reported that there was a significant difference in the perception of headmasters on the practice of transformational leadership according to types of the schools. However, the findings by Talebloo (2015) and Sharma, Sun \& Kannan (2012) stated that the level of transformational leadership practices was not different based on types of schools and nationalities. The findings of the study also revealed that the transformational leadership practices was high at $\mathrm{SJK}(\mathrm{T})$ school compared to SK and $\mathrm{SJK}(\mathrm{C})$ schools as perceived by the teachers. This finding was in line with Selvaraja \& Pihie (2018) findings in Kuala Langat District.

In summary, the high level of transformational leadership practices as perceived by the teachers indicates that overall strategies and effort made by the Ministry of Education in producing transformational leader at school has seen fruitful result as the leadership training given to headmaster have been influential in equalizing the leadership knowledge among the leaders at the three types of schools. The practices of transformational leadership dimensions and overall transformational leadership was significantly different among the three types of school. The highest level of transformational leadership practices at $\mathrm{SJK}(\mathrm{T})$ implies that headmaster at National type Tamil schools able to communicate school mission to staff and students, regularly encourages the teachers to evaluate their progress towards achieving school goals, encourage the teachers to be innovative, work collaboratively with teachers by providing sufficient resources and promotes a caring and trust atmosphere among teachers. Therefore, the Ministry of Education should encourage SK and SJK(C) schools to self-evaluate and increase the practice of transformational leadership.

\section{REFERENCES}

[1] Bass, B. M. (1985). Leadership and performance beyond expectations. New York: Free Press.

[2] Bass, B.M. (1998). Transformational leadership: Industrial, military, and educational impact. Mahwali, NJ: Lawrence Erlbaum Associates.

[3] Burns, J. M. (1978). Leadership. NY: Harper \& Row.

[4] Davrajoo, E., Tarmizi, R.A., Nawawi, M., Hassan, A. (2010). Enhancing algebraic conceptual knowledge with aid of Module using Mastery Learning approach. Procedia - Social and Behavioral Sciences, 8, 362369. doi: $10.1016 /$ j.sbspro.2010.12.051

[5] Hassan, A., Maharoff, M., Abiddin, N.Z., Ro'is, I.Teacher trainers' and trainee teachers' understanding towards the curriculum philosophy regarding soft skills embedment in the Malaysian institute of teacher education(2015) Policy Futures in Education, 14 (2): 164-175. doi: 10.1177/1478210315597857

[6] Hassan, A., Tymms, P., Ismail, H.Academic productivity as perceived by Malaysian academics(2008) Journal of Higher Education Policy and Management, 30 (3): 283-296. doi: 10.1080/13600800802155184

[7] Ismail, H., Hassan, A., Muhamad, M.M., Wan Ali, W.Z., Konting, M.M.(2013). Epistemological belief and learning approaches of students in higher institutions of learning in Malaysia. International Journal of Instruction, 6 (1): 139-150.

[8] Jamilah Man, Yahya Don \& Siti Noor Ismail (2016). Kepimpinan Transformational dan Kualiti Guru Generasi Y. Jurnal Kepimpinan Pendidikan, 3(1): 29-32.

[9] Kamarudin, N., TzeJiun, L., Talib, O., Hassan, A. (2017). Enhancing higher order thinking skills via inquiry-based laboratory practices among science students. Man in India, 97 (17): 185-194.

[10] Khalip Musa (2013). Study of Transformational Leadership in Malaysia Changing Education environment: A Case of High Performing Schools. Management Research Journal, 2(1): 69-79.

[11] Khalip Musa (2013). Study of Transformational Leadership in Malaysia Changing Education environment: A Case of High Performing Schools. Management Research Journal, 2(1): 69-79

[12] Leithwood, K. \& Jantzi, D. (2006). Transformational school leadership for large scale reform; effects on students, teachers and their classroom practices. School Effectiveness and School Improvement, 17(2), 201-228.

[13] Leithwood, K. (2012). The Ontario Leadership Framework: with a Discussion of the Research Foundations. Ontario: The Ontario Institute for Educational Leadership.

[14] Leithwood, K., Harris, A., \& Hopkins, D. (2008). Seven strong claims about successful school leadership. School leadership and management, 28(1), 27-42. 
[15] Leithwood,K.,Jantzi,D.,\& Steinbach,R. (1999). Changing leadership for changing times. Philadelphia: Open University Press.

[16] Ling. T. P., \& Pihie, Z. A. L. (2014). Transformational School Leadership and Malaysian Teachers' Commitment in Structural Equation Modeling Approach. In Proceedings of the Asian Pacific Conference on Edicational Management and Leadership (APCEMaL 2014): Shaping Global Educational Leaders and Managers.

[17] Majid, N. A., Hassan, A., \& Hassan, N. C. (2019). Racial Integration of Multi-Ethnic Students in Malaysia Higher Institutions. International Journal of Academic Research in Business and Social Sciences, 9(12), $608-625$.

[18] Ministry of Education Malaysia. (2013). Malaysia Education Blueprint 2013-2025: Preschool to PostSecondary Education. Putrajaya: Ministry of Education Malaysia.

[19] Nir, A. E., \& Hameiri, L. (2014). School principals' leadership style and school outcomes: The mediating effect of powerbase utilization. Journal of Educational Administration, 52 (2), 210-227.

[20] Nurharani, S., Norshidah, N., \& Afni Anida, A. (2013). Rekindle teacher's organizational commitment: The effect of transformational leadership behavior. Procedia - Social and Behavioral Sciences, 90, 566574. doi:10.1016/j.sbspro.2013.07.127

[21] Salleh, M. J., \& Saidova, P. (2013). Best practice of transformational leadership among multi-ethnic headteachers of primary schools, Malaysia. IOSR Journal Of Humanities And Social Science (IOSRJHSS), 9(3), 1-9.

[22] Saybani, H., Yusof, A., Soon, C., Hassan, A., Zardoshtian, S.Athletes' satisfaction as mediator of transformational leadership behaviors of coaches and football players' sport commitment relationship(2013) World Applied Sciences Journal, 21 (10):1475-1483.

[23] Selvaraja, K., \& Pihie, Z. L. (2015).The Relationship between School Culture and School Innovativeness among National Type Tamil Primary Schools, Sjk (T) S in Kuala Langat District, Selangor. International Journal of Humanities Social Sciences and Education (IJHSSE), 2(1),126-137.

[24] Sharma, S., Sun, H., \& Kannan, S. (2012). A Comparative Analysis on Leadership Qualities of School Principals in China, Malaysia \& India. International Online Journal of Educational Sciences, 4(3).

[25] Sun, J., \& Leithwood, K. (2012). Transformational school leadership effects on student achievement. Leadership and Policy in Schools, 11(4), 418-451

[26] Talebloo, B., Basri, R. B., Asmiran, S. B., \& Hassan, A. (2015). Teachers' Perceptions on Transformational Leadership Based on Demographic Differences. Middle-East Journal of Scientific Research, 23(6), 1105-1113.

[27] Teh, P. L., Pihie, Z. A. L., Asimirin, S., \& Foo, S. F. (2015). The influence of transformational school leadership on teacher efficacy in Malaysian secondary school teachers. International Journal of Social Science Research, 3(2), 73-85. doi.org/10.5296/ijssr.v3i2.7794

[28] Veeriah, J. Chua, Y. P., Siaw, Y. L., and Hoque, K.E. (2017). Teachers' perception on the relationships between transformational leadership and school culture in primary cluster schools. Malaysian Online Journal of Educational Management, 5(4), 18-34

[29] Wahab, N. A., Ahmad, A. R., Jelas, Z. M., Rahman, N. A., \& Halim, L. (2014). The Role and Perspectives of Administrators in the Schools of Orang Asli Students: A Case Study in the State of Pahang. International Proceedings of Economics Development and Research, 78(6), 27-33.

[30] Yu, H., Leithwood, K., \& Jantzi, D. (2002). The effects of transformational leadership on teachers' commitment to change in Hong Kong. Journal of educational administration, 40(4), 368-389.

\section{AUTHORS' BIOGRAPHY}

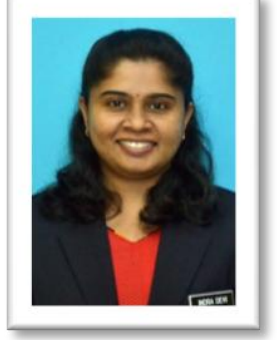

INDRA DEVI MANIAM is a PhD candidate at the Faculty of Educational Studies, University Putra Malaysia. She holds a Master's Degree in Educational Administration from the University Putra Malaysia and Bachelor of Business Administration from University of Malaya. She is currently serving as a primary school teacher under the Ministry of Education Malaysia. Her $\mathrm{PhD}$ thesis is about "The Mediating Effect of School Climate and Teachers' Empowerment on Transformational Leadership and School Effectiveness at Primary Schools". Because of her strong drive and leadership with passion and excitement for education, trigger her to carry out this study. 


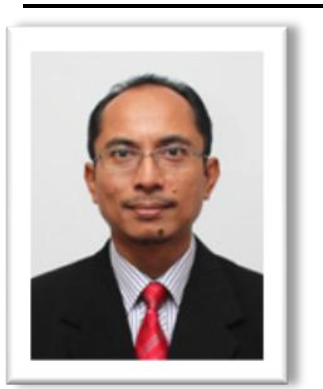

PROFESSORMADYA DR. AMINUDDIN HASSANis a professor at the Faculty of Educational Studies, Universiti Putra Malaysia. He completed his high school at SekolahMenengahSains Melaka, Air Keroh, Melaka. He holds the doctoral degree from Durham University, UK. He was appointed as a Tutor with University Putra Malaysia in 2001 and then to lecturer in 2006. He has been involved in research, teaching and consultancy works, in the area of philosophy of education, higher education, thinking skills and logic.

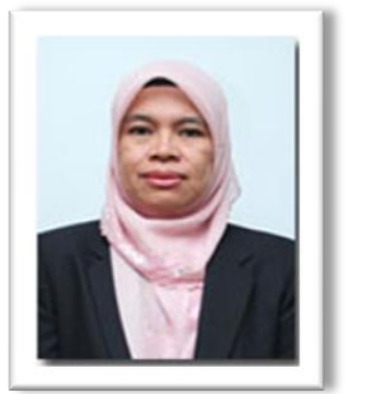

DR ARNIDA ABDULLAHis a Senior Lecturer at the Department of Science and Technical Education, Faculty of Educational Studies at University Putra Malaysia where she has been a faculty member since 2015. Dr. Arnida has completed her Doctoral of Philosophy (Education) at the University of Melbourne, Master of Education at University Kebangsaan Malaysia and Bachelor of Science in Business Administration (Business Economics) at the University of Denver. Her research interests lie in the area of Business Education, Economics Education and Higher Education.

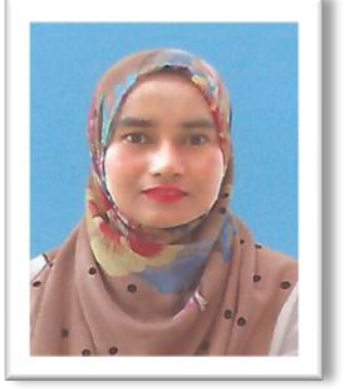

NORAZIELA ABDUL MAJID is a $\mathrm{PhD}$ candidate at the faculty of Educational Studies, Universiti Putra Malaysia. She holds a Master's Degree, Bachelor and Diploma in Tourism Management. Her $\mathrm{PhD}$ thesis is about "Social Interaction as Mediator in Relationship between Racial Integration and Democratic Outcomes among Multi-Ethnic Students in Malaysia Higher Institutions".

Citation: Indra Devi Maniam, et.al. "Teacher's Perception on Transformational Leadership Based on Primary Schools in Peninsular Malaysia" International Journal of Humanities Social Sciences and Education (IJHSSE), vol 7, no. 8, 2020, pp. 88-97. doi: https://doi.org/10.20431/2349-0381.07080010.

Copyright: (C) 2020 Authors. This is an open-access article distributed under the terms of the Creative Commons Attribution License, which permits unrestricted use, distribution, and reproduction in any medium, provided the original author and source are credited. 